\title{
Mitochondrial DNA Sequencing of Middle Neolithic Human Remains of Ling-Ding Site II: Implication for the Social Structure and the Origin of Northeast Coast Taiwaneses
}

Jin-Yuan Huang ${ }^{1}$, Jean A. Trejaut ${ }^{1}$, Chien-Liang Lee ${ }^{1}$, Tse-Yi Wang ${ }^{1}$, Jun-Hun Loo ${ }^{1}$, Zong-Sian Chen ${ }^{1}$, Lan-Rong Chen ${ }^{1}$, Ke-Hung Liu ${ }^{2}$, Yi-Chang Liu ${ }^{3}$, ChengHeng $\mathrm{Hu}^{4}$ and Marie Lin ${ }^{\star *}$

${ }^{1}$ Molecular Anthropology and Transfusion Medicine Research Laboratory, Mackay Memorial Hospital, Taipei City 10449, Taiwan

${ }^{2}$ National Museum of Natural Science. No.1, Guanqian Rd., North Dist., Taichung City 40453, Taiwan

${ }^{3}$ National Cheng Kung University (NCKU), 701 No.1, University Road, Tainan City 701, Tainan, Taiwan

${ }^{4}$ Chinese Culture University, 55 Hwa-Kang Rd., Yang-Ming-Shan, Taipei, 11114 Taiwan

*Corresponding author: Marie Lin, Molecular Anthropology and Transfusion Medicine Research Laboratory, Mackay Memorial Hospital, 45 Min-Sheng Road, Tamsui, 25115, Taiwan, Tel: +886-2 28094661; E-mail: marilin@mmh.org.tw

Received date: April 10, 2018; Accepted date: May 15, 2018; Published date: May 21, 2018

Copyright: (c) 2017 Huang JY, et al. This is an open-access article distributed under the terms of the Creative Commons Attribution License, which permits unrestricted use, distribution, and reproduction in any medium, provided the original author and source are credited.

\section{Abstract}

There is a consensus that gene flow characterizing modern Mainland Chinese arrived in Taiwan during the last 400 years, mostly from East China. However, primary genetic studies of ancient human remains of the middle Neolithic era, revealing inconsistencies between the archaic genes profile and that of modern Mainland Chinese, raised debates about the time of arrival of modern Chinese in Taiwan.

To resolve this problem, this study focuses on the analysis of 3000 years BP human remains excavated from the Neolithic east coast archeological Ling-Ding site II near Hualien in Taiwan. The mitochondrial DNA (mtDNA) recovered from five archeological human remains was analyzed to elucidate their genealogy, and to characterize their genetic relationship with the present-day aboriginal and non-aboriginal people of Taiwan.

Five mtDNA haplogroups were characterized from the Ling-Ding site II skeletons, C4a2, N9a1, B4c1b2a, Z, and $\mathrm{B} 4 \mathrm{~b}$. Except for mtDNA haplogroups $\mathrm{B} 4 \mathrm{c} 1 \mathrm{~b} 2 \mathrm{a}$, commonly seen among the present-day central Taiwan Aborigines and scarce in the heavily sinicised Taiwan western plain tribes, all other haplogroups were common to urban Taiwanese and modern Mainland Chinese. It is proposed that a middle Neolithic gene flow, characterizing Modern Mainland East Asians, was introduced to Taiwan by settlers who reached the East coast of Taiwan in Hualien (LingDing site II) and co-habited with Taiwan Mountain tribe Aborigines. The findings of this study may be relevant for the understanding of the middle Neolithic peopling of Taiwan by non-Austronesian speakers.

Keywords: Ancient DNA; Mitochondrial DNA; Human origins; Taiwan; Molecular genetics; Austronesian speakers

\section{Introduction}

With 23 million inhabitants, Taiwan today is populated by two main groups of peoples, the non-Taiwan Aborigines (non-TwA, 97.5\%) and the Taiwan Mountain tribe Aborigines (TwA, 2.4\%). The great majority of non-TwA today are urban and descendants of Minnan (73.5\%) and Hakka (17.5\%) from the East and Southeast Coast of China, other nonTwA live in the western plains ( $6.5 \%)$. The great majority of non-TwA migrated to Tawain in the past 400 years. Most of the TwA (2.5\%) live on the Taiwan Mountain Range and the east coast of Taiwan. Their languages belong to the Austronesian language family that started in Taiwan 6000 years ago and expanded across Island Southeast Asia (ISEA), Oceania, and the Indian Ocean in the last 3000 years [1,2]. A few groups of these Austronesian speakers, the Taiwan plain tribes (TwPlt), settled in the western plain of Taiwan, they are now heavily sinicised and most of their original languages are presently extinct [3-5].

Past genetic studies, using Histoleucocyte antigens (HLA), nonrecombining Y-chromosome (NRY), mitochondrial DNA (mtDNA), and complete Human genome using Affymetrix Human Origins SNP, have shown that non-TwA and TwA have clearly distinct genetic profiles, and the TwPlt are heavily mixed with non-TwA (approximately $75 \%$ to $90 \%$ ) [6-10]. In addition, more than $85 \%$ of the maternal lineages in TwA are nested within mtDNA haplogroups B4a1, B5a, F1a1, F3b, E1a1, and M7 [9,11-14]. According to genetic and linguistic studies, these haplogroups were acquired in Taiwan from Austronesian speaking agriculturists southeast Asia in early Neolithic $[1,2]$. In contrast, non-TwA groups and TwPlts, have a lower frequency of these mtDNA haplogroups, instead, most of their profile is represented by descendants of mtDNA haplogroups $A, C, D 4, G, M 9$, M10 and $\mathrm{Z}$ which are commonly seen among the present-day populations of continental East Asia. It is generally believed that these haplogroups represent gene flow over the past 400 years from expanding continental East Asian populations, such as Minnan and Hakka. The finding of Mainland Asia genetic characteristics among ancient human remains from other archeological sites in Taiwan [15] has been the subject of debates among archeologists and anthropologists.

How much of the initial Neolithic genetic changeover in Taiwan coincided with a substantial gene flow from China is still unknown. The degree of genetic relationships between the ancient and modern 
Citation: Huang JY, Trejaut JA, Lee CL, Wang TY, Loo JH, et al. (2018) Mitochondrial DNA Sequencing of Middle Neolithic Human Remains of Ling-Ding Site II: Implication for the Social Structure and the Origin of Northeast Coast Taiwaneses. J Phylogenetics Evol Biol 6: 200. doi:10.4172/2329-9002.1000200

Page 2 of 6

populations of Taiwan, and whether there is genetic continuity between them remain to be determined. In this study, we compared the mtDNA genetic makeup of living aboriginal and non-aboriginal native of Taiwan to the genetic profile obtained from five ancient human remains of the Lin-Ding archeological site II, in Hualien on the East coast of Taiwan, dating back to the middle Neolithic era 3,000 years BP. This analysis should help anthropologists and archaeologists explain the genetic origin of the Taiwanese, and address matters that cannot be treated with traditional methods.

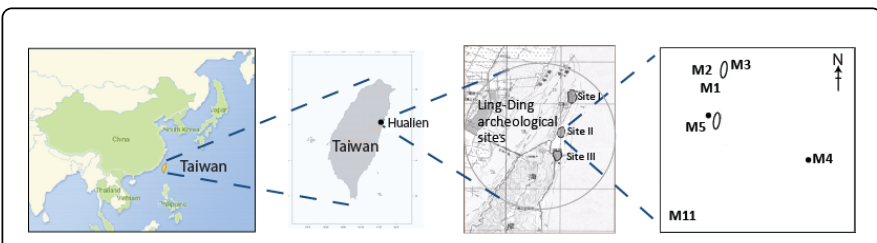

Figure 1: Location of ancient human remains of the archeological Ling-Ding site II in Hualien.

\section{Materials and Methods}

\section{Samples}

Ling-Ding Site II in Hualien on the east coast of Taiwan (Figure 1) provided 6 different ancient human skeletal remains of which 8 teeth samples were suitable for DNA analysis. Radiocarbon dating, using accelerator mass spectroscopy (AMS) of one tooth LD-M11, indicated an age estimate of 2950 3160 years (Table 1). Accordingly, using artifacts, stratigraphic and chronological relationship to LD-M11, other samples on site II were assigned to a mid-Neolithic age most likely older than 2950 years BP.

\section{Silica-Based ancient DNA purification}

Ancient DNA (aDNA) extracts and handling of the teeth were carried out in a laboratory dedicated exclusively for ancient human remains where no modern human DNA preparation or polymerase chain reaction (PCR) has ever been performed. aDNA purification was carried out according to the protocol described by Rohland and Hofreiter [16] with minor modifications. Briefly, teeth pulp was grounded to powder $(0.1 \sim 0.05 \mathrm{~g})$ using a bleached dental drill and was added to an extraction buffer (0.5 M EDTA, 1\% Sodium Diodecil Sulphate, $0.25 \mathrm{mg} / \mathrm{ml}$ proteinase $\mathrm{K}, \mathrm{pH} 8.0$ ) for approximately $24 \mathrm{hrs}$ at $55^{\circ} \mathrm{C}$. After centrifugation at $3500 \times \mathrm{g}$ for 15 minutes, the supernatant was transferred to a $1 \mathrm{ml}$ binding buffer ( $5 \mathrm{M} \mathrm{GuSCN}, 25 \mathrm{mM} \mathrm{NaCl}, 50$ $\mathrm{mM}$ Tris) supplemented with a $100 \mu$ silica suspension and set on rotation for $3 \mathrm{~h}$ at room temperature. The pellet was washed twice in buffer (50\% alcohol, $0.1 \mathrm{M} \mathrm{NaCl}, 1 \mathrm{mM}$ EDTA, $10 \mathrm{mM}$ Tris), air-dried for $15 \mathrm{~min}$, dissolved in distilled $\mathrm{H}_{2} \mathrm{O}$ for ten minutes at $56^{\circ} \mathrm{C}$ and stored at $-20^{\circ} \mathrm{C}$.

\section{PCR amplification of Mitochondrial DNA}

Each $20 \mu \mathrm{l}$ amplification reaction contained $2 \mu \mathrm{l}$ of DNA extract, 60 $\mathrm{mM}$ Tris- $\mathrm{SO}_{4}$ ( $\mathrm{pH}$ 8.9), $18 \mathrm{mM}$ Ammonium Sulfate, Bovine Serum Albumin $10 \mu \mathrm{g}, 2 \mathrm{mM} \mathrm{MgSO}$, $0.2 \mathrm{mM}$ dNTPs and 0.5 unit of Taq polymerase (Platinum Taq High Fidelity; Invitrogen, USA). Negative controls were included for every set of PCR reactions. A modern DNA positive control was finally added to each set of reactions outside the aDNA PCR-setup laboratory. Seven overlapping segments covering the entire hypervariable segment-I (HVS-1) of the mtDNA control region were amplified using primer sequence pairs listed in Table 2.

\begin{tabular}{|l|l|l|l|l|l|}
\hline $\begin{array}{l}\text { Beta Sample } \\
\text { number }\end{array}$ & Human remains & $\begin{array}{l}\text { Measured radiocarbon } \\
\text { age (years BP) }\end{array}$ & $\begin{array}{l}\text { 13C/12C } \\
\text { (o/oo) }\end{array}$ & $\begin{array}{l}\text { Conventional } \\
\text { age (years BP) }\end{array}$ & Calibrated years BP (2-Sigma) \\
\hline Beta-373818 & LD-M11 & $2950 \pm 30$ & 12.2 & $3160 \pm 30$ & $3450-3345(95 \%)$ \\
\hline & LD-M1 & na & & & \\
\hline & LD-M2 & na & & & \\
\hline & LD-M3 & na & na & & \\
\hline & LD-M4 & na & & & \\
\hline na: not applicable & LD-M5 & & & & \\
\hline
\end{tabular}

Table 1: Ling-Ding radiocarbon dating of ancient human remains.

Determination of additional informative mutations used to obtain more accurate haplogroup assignments was obtained from the sequencing of pertinent segments of the coding region using primer pairs $8,9,10,11$, and 12 (Table 2) chronologically.

Sequencing was performed using Big Dye terminator kit (ABI, Taiwan) in a final volume of $10 \mu \mathrm{l}$ containing $2.5 \mathrm{x}$ Ready Reaction Premix, 5x BigDye sequencing buffer, 3.2 pmol primers and $2 \mu \mathrm{l}$ template. PCR conditions were as follows: 30 cycles of heat treatment at $96^{\circ} \mathrm{C}$ for $20 \mathrm{~s} ; 50^{\circ} \mathrm{C}$ for $20 \mathrm{~s}$, and $60^{\circ} \mathrm{C}$ for $60 \mathrm{~s}$. A purification step using a G50 Sephadex column (Pharmacia, Taiwan) was performed before the final run on an automated DNA sequencer (ABI model 3730). Negative controls were included in both stages of the assay (extraction and PCR) to assess for the potential contamination. All relevant personnel in this study had their mtDNA typed. The two researchers who took the samples from the Ling-Ding site had mtDNA matching haplogroups $\mathrm{H}$ and M10b, and all aDNA work was carried out by JYH who matched mtDNA haplogroup N9a10. 
Citation: Huang JY, Trejaut JA, Lee CL, Wang TY, Loo JH, et al. (2018) Mitochondrial DNA Sequencing of Middle Neolithic Human Remains of Ling-Ding Site II: Implication for the Social Structure and the Origin of Northeast Coast Taiwaneses. J Phylogenetics Evol Biol 6: 200. doi:10.4172/2329-9002.1000200

Page 3 of 6

\begin{tabular}{|l|l|l|l|l|l|}
\hline $\begin{array}{l}\text { Primer } \\
\text { pairs }\end{array}$ & Primer Names & Forward Primer (5' to $\left.\mathbf{3}^{\prime}\right)$ & $\begin{array}{l}\text { Primer } \\
\text { Names }\end{array}$ & Reverse Primer (5' to $\left.\mathbf{3}^{\prime}\right)$ & $\begin{array}{l}\text { Amplified } \\
\text { regions }\end{array}$ \\
\hline 1 & L15995 & TCCACCATTAGCACCCAAAG & H16118 & TTTATGGTACCGTACAATATTC & $15995-16118$ \\
\hline 2 & L16079 & GTATTGACTCACCCATCAAC & H16196 & TGCTGTACTTGCTTGTAAGC & $16079-16196$ \\
\hline 3 & L16176 & GTACATAAAAACCCAATCCAC & H16329 & TGACTGTAATGTGCTATGTAC & $16176-16329$ \\
\hline 4 & L16250 & TCACACATCAACTGCAACTC & H16404 & ATATTGATTTCACGGAGGATG & $16250-16404$ \\
\hline 5 & L16358 & ACATTACAGTCAAATCCCTTC & H16483 & AGATGTCGGATACAGTTCAC & $16358-16483$ \\
\hline 6 & L16449 & ACAAGAGTGCTACTCTCCTC & H21 & AGCTCCCGTGAGTGGTTAAT & $16449-21$ \\
\hline 7 & L16542 & AAAGCCTAAATAGCCCACAC & H114 & AGACAGATACTGCGACATAG & $16542-114$ \\
\hline 8 & L143 & AGTATCTGTCTTTGATTCCTG & H268 & TTTGTTATGATGTCTGTGTGG & $143-268$ \\
\hline 9 & L5972 & ACACTATACCTATTATTCGGC & H6081 & ATTATTACAAATGCATGGGC & 5972-6081 \\
\hline 10 & L10280 & AAATTGCCCTCCTTTTACCC & H10431 & TCATAATTTAATGAGTCGAAATC & $10280-10431$ \\
\hline 11 & L10779 & AATGCTAAAACTAATCGTCCC & H10903 & TTGGGGAACAGCTAAATAGG & $10779-10903$ \\
\hline 12 & L14535 & AACCCATATAACCTCCCCC & H14698 & TGGTTTTTCATATCATTGGTC & $14535-14698$ \\
\hline
\end{tabular}

Table 2: Primer sequences used for aDNA amplification of the HVS1control region and other relevant coding regions.

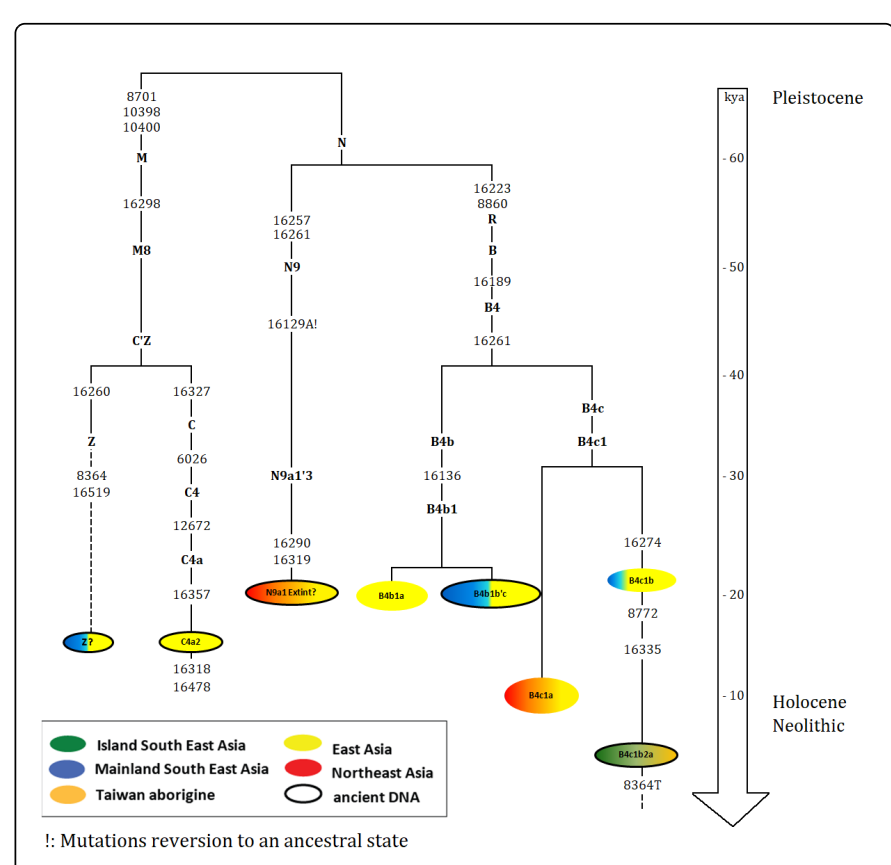

Figure 2: Phylogenetic tree restricted to Ling-Ding site II results (modified from Brandao's et al. [11]). Shadings represent the geographic relative distribution of mtDNA haplogroups across Asian regions. Black circles shadings indicate haplogroups detected in the ancient human remains of Ling-Ding Site II. Nucleotide positions are only those indicated in Table 3.

\section{Results}

Five of the six ancient human remains from the Ling-Ding archeological site (Figure 1) produced successful mtDNA extracts.
Further, on the basis of remains surrounding each burial, specimens that were not carbon dated were categorized as belonging to the same period as specimen LD-M11 (approximately 3000 years BP) (Table 1) and their genetic structure was anticipated to represent the characteristics of Taiwan people in middle Neolithic time.

\section{C4a2 sample LD-M1}

Haplogroup C (Figure 2 and Table 3 ) is a descendant of Haplogroup M. The C4a2 subtype originated approximately 15,000 years BP [17] and branches of this clade, such as C4a2a, are commonly seen in the Evenki and Tuva of Siberia [18]. Further, population dispersals of C4a2 from these regions resulted in the presence of $\mathrm{C} 4 \mathrm{a} 2 \mathrm{~b}$ and $\mathrm{C} 4 \mathrm{a} 2 \mathrm{c}$ in the Himalayas, Tibet and Indian regions [19]. C4a2 has not been seen among Austronesian speaking groups, such as TwA, the Philippines or Indonesia $[20,21]$, and the subtype seen in this study is a new type that is only seen at low frequency $(<1 \%)$ among non-TwA (Lin M, personal communication). Accordingly, the presence of C4a2 in any Taiwan individual will associate to a continental East Asian origin.

\section{N9a1 sample LD-M2}

Branches of haplogroup N9a (Figure 2 and Table 3) are mostly seen in Mongolia (2.1\%), northeastern China (2.8\%), Korea (2.1\%), Japan (4.6\%) [18], and Mainland southeastern Asia (MSEA) (1.5-4.5\%) [22]. The type seen in Taiwan (N9a10) (2-7\%) is unique to Amis, Puyuma, Atayal, and Toroko, and scarce among non-TwA $(<1 \%)$. It has not been reported in Mainland China. The N9a1 type found in ancient human remain LD-M2 (Table 3) has not been described elsewhere [17]. According to Phylotree [17], it appears to be an extinct branch of N9a1 and cannot be confidently given a label of continental East Asian or TwA origin. 
Citation: Huang JY, Trejaut JA, Lee CL, Wang TY, Loo JH, et al. (2018) Mitochondrial DNA Sequencing of Middle Neolithic Human Remains of Ling-Ding Site II: Implication for the Social Structure and the Origin of Northeast Coast Taiwaneses. J Phylogenetics Evol Biol 6: 200. doi:10.4172/2329-9002.1000200

Page 4 of 6

\begin{tabular}{|c|c|c|c|c|c|c|c|c|c|c|c|c|c|c|c|c|c|c|c|c|c|c|c|c|c|c|c|c|c|}
\hline & \multicolumn{28}{|c|}{ Nucleotide positions } & \\
\hline & \multicolumn{9}{|c|}{ Coding region } & \multicolumn{19}{|c|}{ Control region (HVS1) } & \\
\hline & 6 & 8 & 8 & 8 & 8 & 9 & 1 & 1 & 1 & 1 & 1 & 1 & 1 & 1 & 1 & 1 & 1 & 1 & 1 & 1 & 1 & 1 & 1 & 1 & 1 & 1 & 1 & 1 & \\
\hline & 0 & 3 & 7 & 7 & 8 & 8 & 0 & 0 & 2 & 6 & 6 & 6 & 6 & 6 & 6 & 6 & 6 & 6 & 6 & 6 & 6 & 6 & 6 & 6 & 6 & 6 & 6 & 6 & \\
\hline & 2 & 6 & 0 & 7 & 6 & 2 & 3 & 4 & 6 & 1 & 1 & 2 & 2 & 2 & 2 & 2 & 2 & 2 & 3 & 3 & 3 & 3 & 3 & 3 & 3 & 3 & 4 & 5 & \\
\hline & 6 & 4 & 1 & 2 & 0 & 4 & 9 & 0 & 7 & 3 & 8 & 2 & 5 & 6 & 6 & 7 & 9 & 9 & 1 & 1 & 1 & 2 & 3 & 5 & 5 & 9 & 7 & 1 & \\
\hline Sample ID & & & & & & & 8 & 0 & 2 & 6 & 9 & 3 & 7 & 0 & 1 & 4 & 0 & 8 & 1 & 8 & 9 & 7 & 5 & 5 & 7 & 0 & 8 & 9 & Haplogroups \\
\hline$\overline{\text { CRS }}$ & $\mathrm{G}$ & $\mathrm{A}$ & A & $\mathrm{T}$ & $\bar{A}$ & $\mathrm{~T}$ & $\mathrm{~A}$ & $\mathrm{C}$ & $\overline{\mathrm{A}}$ & $\mathrm{T}$ & $\mathrm{T}$ & $\mathrm{C}$ & $\mathrm{C}$ & $\mathrm{C}$ & $\mathrm{C}$ & $\mathrm{G}$ & $\mathrm{C}$ & $\mathrm{T}$ & $\mathrm{T}$ & $\mathrm{A}$ & $\mathrm{G}$ & $\mathrm{C}$ & $\mathrm{A}$ & $\mathrm{C}$ & $\mathrm{T}$ & $\mathrm{G}$ & $\mathrm{C}$ & $\mathrm{T}$ & \\
\hline LD-M1 & A & - & - & - & - & - & $\mathrm{G}$ & $\mathrm{T}$ & G & & & $\mathrm{T}$ & & & & & & $\mathrm{C}$ & & G & & $\mathrm{T}$ & & & $\mathrm{C}$ & & $\mathrm{T}$ & $\mathrm{C}$ & $\mathrm{C} 4 \mathrm{a} 2$ \\
\hline LD-M2 & - & - & - & - & - & & - & - & - & - & - & $\mathrm{T}$ & $\mathrm{T}$ & & $\mathrm{T}$ & & $\mathrm{T}$ & & & & A & & & & & & - & - & N9al (Extinct) \\
\hline LD-M4 & - & G & - & $\mathrm{C}$ & G & - & - & - & - & & & & & & & $\mathrm{A}$ & & & & & & & G & & & & - & - & $\mathrm{B} 4 \mathrm{c} 1 \mathrm{~b} 2 \mathrm{a}$ \\
\hline LD-M5 & - & G & G & & $\mathrm{T}$ & - & $\mathrm{G}$ & $\mathrm{T}$ & - & & & $\mathrm{T}$ & & $\mathrm{T}$ & & & & $\mathrm{C}$ & & & & & & & & & - & - & Z \\
\hline LD-M11 & - & - & - & - & - & - & & & - & $\mathrm{C}$ & $\mathrm{C}$ & - & - & - & - & - & - & - & - & - & - & - & - & - & - & - & - & - & B4b1 \\
\hline
\end{tabular}

Table 3: Mitochondrial sequence variations in five ancient human remains of Ling-Ding site II and haplogroup assignments.

\section{B4c1b2a sample LD-M4}

Haplogroup B4c1b2a (Figure 2 and Table 3) is seen in most Austronesian speaking groups. Variants of B4c1b2a have been seen in the Philippines, Orchid Island, western ISEA, and Malaysia [11]. In Taiwan, among Atayal, Yami, Puyuma, and Tsou, it is seen as haplogroup B4c1b2a2a and is characterized by two extra nucleotides, T195C and G15301A that differentiate it from its sister types seen among non-TwA and other groups from South and East China [17]. The quality of aDNA retrieved from LD-M4 did not allow further determination than $\mathrm{B} 4 \mathrm{c} 1 \mathrm{~b} 2 \mathrm{a}$, and accordingly, the type could not be associated to either, a non-TwA or TwA ancestry.

\section{Z sample LD-M5}

Haplogroup Z (Figure 2 and Table 3), most likely arose in Siberia and central Asia 15,800 $\pm 4,400$ years BP [23]. Subtypes of $Z$ are seen at low frequency $(<2 \%)$ throughout East Asia, among non-TwA, and the Philippines. Here, the finding of $\mathrm{Z}$ in ancient remain LD-M5 is most likely associated to a continental East Asian ancestry.

\section{B4b sample LD-M11}

Most members of the B4b (Figure 2 and Table 3) clade are seen in Mainland Southeast Asia (Indochina), Taiwan and the Philippines [9,11-13], but also in Japan and Siberia [24]. Subtypes of B4b in nonTwA are principally represented by subtypes of B4b1b, B4b1c, and B4b1a1. Conversely, in Austronesian speaking groups, it is seen as subtypes of B4b1a2. The sole carbon dated specimen of the Ling-Ding site II, LD-M11 (Table 1 and 3) could only be assigned to haplogroup B4b1. A TwA or a Mainland East Asian label could not be characterized.

\section{Discussion}

In this study, we applied molecular genetics on ancient human remains of the middle Neolithic archaeological Lin-Ding site II of Hualien on the east coast of Taiwan in search for a better understanding of the origins and affinities of the autochthonous populations of Taiwan. We primarily analyzed the polymorphisms of mtDNA coding-regions (nps 8,000-9,000 and 10,000-11,000) and control region HVSI (nps 16,030 to 16,490), and then used other pertinent SNPs of the coding region for proper haplogroup assignments. Dedicated ancient DNA laboratory, contamination controls and mtDNA typing of archaeologists and laboratory researchers participating in the research project were done to ascertain the authenticity of all ancient specimen analyzed.
The mtDNA sequences of five ancient human remains were obtained. All sequences assignments, B4c1b2a, B4b, C4a2, N9a1, and Z (Figure 2), had a distinct geographical association with populations of continental East Asia and revealed information about their prehistoric source of ethnicity back to more than 15,000 years BP. Two sequences, C4a2 and Z (LD-M1 and LD-M5 respectively) commonly seen in modern continental East Asians, suggested the presence of such people in the middle Neolithic on the East coast of Taiwan. This profile is not as clearly defined by the three other haplogroups, namely B4c1b2a, B4b1, and N9a1 since the depth of the sequencing attained was not sufficient to assign confidently these haplogroups to a TwA or nonTwA specificity (Table 3). Most likely, B4c1b2a was representing a TwA as the frequency of this haplogroup is twice higher among northern and central Taiwan Aborigines $[9,12]$ than southern TwA or non-TwA. Conversely, B4b1 and N9a1 are more commonly seen among nonTwA, and consequently, their presence among present-day TwA is usually regarded as the result of continental East Asian gene flow. Although the haplogroups mentioned above do not represent the polymorphism profile expected from the whole analysis of the burial site, the estimated dating of the Ling-Ding site, 3,160 years BP, represent a minimum of 60 generations of 25 years [25,26], and the polymorphism represented by these mtDNA haplogroups indicates that middle Neolithic settlers from the continental East Asia, arrived there as a group composed of a significant number of non-TwA females and males.

\section{Finding expectation}

The determination, in Ling-Ding Site II, of two possible ethnically distinct gene pools, one associated with a 3,000 years BP continental origin bearing the same genetic profile as present-days continental East Asians, and the other being the result of a Taiwan Aboriginal genetic expansion, requires the analysis of more ancient remains to be evidenced. Nonetheless, the presence of continental East Asian settlers on the East coast of Taiwan and the possibility of their cohabitation with nearby TwA can confidently be ascertained and opens new insights about their social organization, collaboration, and genetic sinicisation. This is supported by the archaeology report of Ling-Ding site [27] which propose a hierarchy in the distribution of burials between rich and poor individuals based on the presence of fine chorded ware, stones relics, fine jades artifacts, and the information given by the structural and elaborate arrangement of the burials (Figure 1). 
Citation: Huang JY, Trejaut JA, Lee CL, Wang TY, Loo JH, et al. (2018) Mitochondrial DNA Sequencing of Middle Neolithic Human Remains of Ling-Ding Site II: Implication for the Social Structure and the Origin of Northeast Coast Taiwaneses. J Phylogenetics Evol Biol 6: 200. doi:10.4172/2329-9002.1000200

Page 5 of 6

\section{Did these ancient non-TwA settlers circumnavigate Taiwan or walk to Ling-Ding site II?}

Migration routes of Formosan speakers within Taiwan reported by Paul Li [5] suggest historical migrations associated with specific tribes. Most are short distance displacements of tribes finally reaching their present-day settlement in the Mountain range. Only the Amis covered long coastal marches to finally reach Hualien, and the Sediq tribe a cross range migration to reach the northern region of Hualien. These two migrations routes can represent the routes followed by the continental East Asian settlers of Ling-Ding. Alternatively, these middle Neolithic Mainlanders had navigation skills and technology that could have permitted them to circumnavigate the Island.

Their arrival 3,000 years BP intriguingly corresponds to the "out of Taiwan diaspora (OOT) [1] of which gene flow also includes mtDNA polymorphism of modern Southeast Asians and South Chinese [28]. It is possible that it is the presence of ancient non-TwA settlers who triggered the OOT.

\section{Why more non-TwA than TwA in Ling-Ding site II?}

Before the twentieth century, Taiwan Aborigines were more commonly burying their deads in the house or in the village graveyard without coffins [29]. Conversely, burial with coffins or urn in a community site by Mainland East Asians is the general practice [30] The high level of non-TwA genetic profile found in the Ling-Ding site II is therefore expected, and should probably be also expected in any other well-structured middle Neolithic burial sites throughout Taiwan.

\section{Culture and genetic profile}

As proposed above, the Ling-Ding archaeological site represents a middle Neolithic colonization event of Taiwan by non-TwA and characterizes an East coast region composed of genetically mixed ethnic groups with a complex social organization. It also supports previous finding of Mainland associated mtDNA lineages in other archaeological sites of Taiwan [15,31]. Furthermore, the traces of Fine Corded Ware Culture found in Ling-ding site II (also known as the Red Corded Ware Culture or Huagangshan culture) brings a supporting element for a proposed association between Fine Corded ware and the Longshanoid culture of Mainland China [15,32].

Finally, the primary state of this project makes it necessary to exercise caution when interpreting these findings. In the future, greater sample size studies of complete genome analysis of any extant populations and ancient human remains in Taiwan, will allow a) to differentiate with more confidence those traits or lineages associated to prehistory from those associated to the last 400 years of Taiwan written history, b) to construct a more complete picture of the Taiwanese human prehistory and allowing retracing migration according to space and time, c) to determine better genetic association between archaeological cultures and genetic, d) to define the relationship of ancient human remains to modern human groups in Taiwan.

\section{Conclusion}

While still in its infant stage, the results obtained here were most surprising, first, because there is a strong public belief that the genetic of all ancient human remains of archaeological sites in Taiwan are associated with Taiwan mountain tribe Aborigines, and second, because out of five ancient human remains dating 3000 years BP, it was unexpected to find two possible mountain tribes associated haplogroups and three mainland-Asia associated haplogroups, therefore moving the historical sinicization of autochthonous Taiwanese into a prehistorical landscape.

New insights into the prehistorical population relationships between Taiwan and Continental Asia have been shown, indicating various possible population dispersals in the middle Neolithic period, and while greatly helping our understanding on the demography of Taiwan, it brings new lights on our understanding of human migration in Taiwan and island Southeast Asia.

\section{Conflict of Interest Statement}

To my knowledge I declare that no economic interest or any conflict of interest exists.

\section{Funding}

This work was supported by a grant NSC 98-2410-H-195-001 from the National Science Council of Taiwan. The funders had no role in study design, data collection and analysis, decision to publish, or preparation of the manuscript.

\section{Authors' Contributions}

The project was conceived and designed by JYH and JAT and JYH performed the laboratory work. JYH and JT performed data analysis and drafted the manuscript. All other authors gave useful contribution on the analysis of data and text of the manuscript. All authors have read and approved the final version of the manuscript.

\section{Acknowledgements}

The authors wish to thanks Doctors Ho CK, Liu KH, Hu CH and Yen LD from the National Museum of Natural Sciences for their help and feedback during manuscript preparation. This work was using the Molecular Antropology database of the Mackay Memorial Hospital of Tamsui in Taiwan.

\section{References}

1. Bellwood P (2004) Southeast Asia, from prehistory to history: In The origin and dispersals and dispersal of agricultural communities in Southest Asia ed EbiGap Bellwood, London and New York: Routledge Curson, Taylor \& Francis group. Edited by Ian Glover and Peter Bellwood 21-40.

2. Diamond J, Bellwood P (2003) Farmers and their Languages: the first expansions. Science 300: 597-603.

3. Blundell D (2000) "Austronesian Taiwan" Linguistics, History, Ethnology, Prehistory. Language connecting the world., ed. D. Blundell, Berkeley, CA: Phoebe A. Hearst Museum, University of California. 401-459.

4. Blust R (1999) Subgrouping, circularity and extinction: some issues in Austronesian comparative linguistics. Symp Ser Ins Linguis Acad Sinica 1: $31-94$.

5. Li PJK (2001) The Dispersal of The Formosan Aborigines in Taiwan. Languages and Linguistics 2: 271-278.

6. Chu CC, Lee HL, Trejaut JA, Lin M (2004) HLA-A, -B, -Cw and -DRB1 allele frequencies in Ami, Atayal, Bunun. Hakka, Paiwan, Pazeh, Puyuma, Rukai, Saisiat, Tsou, Taroko, Thao and Tao populations from Taiwan. Human Immunology. Special Issue: HLA alleles and other immunogenetic polymorphism frequencies from world wide populations. Guest editors: Derek Middelton, John Sanil Manavalan, Marcelo A. Fernandes-Vina. ASHI 65: 1102-1181. 
Citation: Huang JY, Trejaut JA, Lee CL, Wang TY, Loo JH, et al. (2018) Mitochondrial DNA Sequencing of Middle Neolithic Human Remains of Ling-Ding Site II: Implication for the Social Structure and the Origin of Northeast Coast Taiwaneses. J Phylogenetics Evol Biol 6: 200. doi:10.4172/2329-9002.1000200

Page 6 of 6

7. Lin M, Chu CC, Chang SL, Tokunaga K (2001) The origin of Minnan and Hakka, the so-called "Taiwanese", inferred by HLA study. Tissue Antigens 57: 192-199.

8. Skoglund P, Reich D (2016) A genomic view of the peopling of the Americas. Curr Opin Genet Dev 41: 27-35.

9. Trejaut JA, Kivisild T, Loo JH, Lee CL, He CL, et al. (2005) Traces of archaic mitochondrial lineages persist in Austronesian-speaking Formosan populations. PLoS Biol 3: e247.

10. Trejaut JA, Poloni ES, Loo JH, Lin M (2014) Taiwan Y-chromosomal DNA variation and its relationship with Island Southeast Asia. BMC Genet 15: 77-83.

11. Brandao A, Eng K, Rito T, Cavadas B, Bulbeck D, et al. (2016) Quantifying the legacy of the Chinese Neolithic on the maternal genetic heritage of Taiwan and Island Southeast Asia. Hum Genet 135: 363-376.

12. Ko AM, Chen CY, Fu Q, Delfin F, Li M, et al. (2014) Early Austronesians: into and out of Taiwan. Am J Hum Genet 94: 426-436.

13. Soares P, Trejaut JA, Loo JH, Richards M (2008) Climate change and postglacial human dispersals in southeast Asia. Mol Biol Evol 25: 1209-1218.

14. Tabbada KA, Trejaut JA, Loo JH, Chen YM, Lin M, et al. (2010) Philippine mitochondrial DNA diversity: a populated viaduct between Taiwan and Indonesia? Mol Biol Evol 27: 21-31.

15. Lin HM (2009) The Biological Evidence of the San-Pau-Chu Peoples and Their Affinities, in Archeology, digitalrepository.unm.edu/anth_etds/43. University of New Mexico. Albuquerque: New Mexico, Albuquerque.

16. Rohland N, Hofreiter M (2007) Ancient DNA extraction from bones and teeth. Nat Protoc 2: 1756-1762.

17. van Oven M, Kayser M (2009) Updated comprehensive phylogenetic tree of global human mitochondrial DNA variation. Hum Mutat 30: E386-394.

18. Derenko M, Malyarchuk B, Grzybowski T, Denisova G, Rogalla U, et al. (2010) Origin and post-glacial dispersal of mitochondrial DNA haplogroups C and D in northern Asia. PLoS One 5: e15214.

19. Yao YG, Kong QP, Wang CY, Zhu CL, Zhang YP (2004) Different matrilineal contributions to genetic structure of ethnic groups in the silk road region in china. Mol Biol Evol 21: 2265-2280.

20. Delfin F, Min-Shan Ko A, Li M, Gunnarsdóttir ED, Tabbada KA (2014) Complete mtDNA genomes of Filipino ethnolinguistic groups: a melting pot of recent and ancient lineages in the Asia-Pacific region. Eur J Hum Genet 22: 228-237.

21. Cox MP (2005) Indonesian Mitochondrial DNA and Its Opposition to a Pleistocene Era Origin of Proto-Polynesians in Island Southeast Asia. Human Biology 77: 179-188.

22. Peng MS, He JD, Liu HX, Zhang YP (2011) Tracing the legacy of the early Hainan Islanders-a perspective from mitochondrial DNA. BMC Evol Biol 11-46.

23. Behar DM, van Oven M, Rosset S, Metspalu M, Loogva“li EL, et al. (2012) A "Copernican" reassessment of the human mitochondrial DNA tree from its root. Am J Human Genet 90: 675-684.

24. Tanaka M, Cabrera VM, Gonzalez AM, Larruga JM, Takeyasu T, et al. (2004) Mitochondrial genome variation in eastern Asia and the peopling of Japan. Genome Res 14: 1832-1850.

25. Liu YC, Yen TY (2002) Research on the Connotation and Scope of Prehistoric Sites in Taitung County - East Coast and Green Island. Taitung County government Commissioned by Academia Sinica Institute of History and Philology. Taipei, Taiwan 148.

26. Lien CM, Sung WH (2003) Taiwan Neolithic Puyuma. National Museum of History Press.

27. Ho CK, Liu KH, Hu CH, Yen LD (2007) Burials of the Lingding Site of Hualien County, Taiwan Archeological Report 2006. National Museum of Natural Sciences, May 5-6.

28. Soares PA, Trejaut JA, Rito T, Cavadas B, Hill C, et al. (2016) Resolving the ancestry of Austronesian-speaking populations. Hum Genet 135: 309-326.

29. Cauquelin J (2004) The Aborigines of Taiwan, The Puyuma from head hunting to the mordern world.

30. Routledge Curson, Taylor \& Francis group e-library, Londaon and New York. ISBN 0-415-31413-5.

31. Bai Y (2012) A Study of Urn-Burials in the Warring States and Qin. Han periods. Chinese Archaeology 2: 33-39.

32. Chen YF, Lee KS, Cheng HY, Hsu M (2007) Mitochondrial DNA Analysis of an Ancient Population in Southwestern Taiwan. J Genet Mol Biol 18: $18-22$. 